\title{
Treated ANDAMOOKa Matrix Opal
}

By Grahame Brown

Matrix opal from Andamooka, in South Australia, is a precious opal-included porous rock that is commonly color enhanced (carbon impregnated) to imitate the highly prized black opal from Lightning Ridge in northern New South Wales, Australia. This material has been commercially available since the mid-1950s and is often referred to as "sugar treated." A basic sugar acidcarbonizing technique is used to carbonize, and thus darken, the cream-colored matrix of prepolished stones so that the play-of-color is more prominent. The carbon impregnator in treated Andamooka matrix opal can be readily identified with low-power magnification.

The carbon impregnation of matrix opal from Andamooka, in South Australia, has produced many thousands of carats of treated opal with a broad range of appearances (figure 1). Most untreated matrix opal from Andamooka displays little play-of-color and is virtually worthless (figure 2). However, carbon impregnation of the matrix creates a dark body color that shows off the play-ofcolor, producing stones that may resemble black opal from Lightning Ridge and other localities (figure 3). Today, sugar-acid treatment of matrix opal forms the basis of many small commercial enterprises throughout Australia, and treated Andamooka matrix opal is available worldwide. This article discusses the occurrence of Andamooka matrix opal, its treatment, and methods that may be used to assure its identification.

\section{THE LOCATION AND}

\section{OCCURRENCE OF MATRIX} OPAL AT ANDAMOOKA

The Andamooka opal fields are located a little over $500 \mathrm{~km}$ north-northwest of Adelaide, near the northwest edge of Lake Torrens, in South Australia (figure 4). The South Australia Department of Mines and Energy estimated that in 1988 the Andamooka fields, at $\$ \mathrm{~A} 3$ million, were the third most important opal deposit in Australia, in terms of value of rough produced (SADME, 1989); they followed Mintabie (\$A39 million) and Coober Pedy (\$A21 million).

According to Barnes and Townsend (1982), precious opal usually occurs at Andamooka in an essentially horizontal layer at or near the contact

\section{ABOUT THE AUTHOR}

Dr. Brown is the principal of ALLGEM Services. Brisbane, Queensland, Australia, and current president of the Gemmological Association of Australia.

Acknowledgments: The author thanks Corinne Sutherland, of Melbourne, for providing specimens of treated Andamooka matrix opal for this article. The thoughtful reviews of this paper by Jack Townsend and John Keeling, of the South Australian Department of Mines and Energy, are most appreciated. Photos not otherwise attributed are by the author.

Gems \& Gemology, Vol. 27, No. 2, pp. 100-106

(C) 1991 Gemological Institute of America 


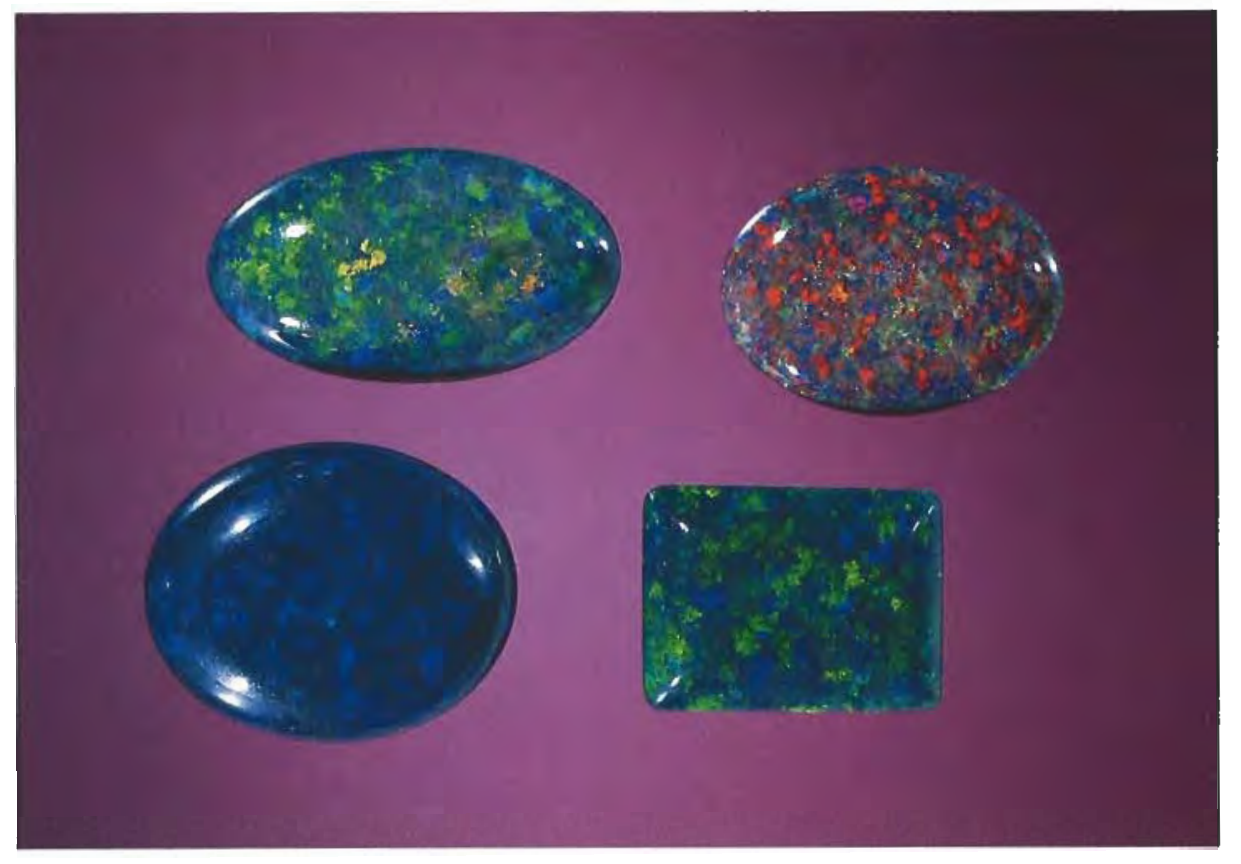

Figure 1. A variely of appearances result from carbon impregnation ("sugar treatment") of Andamooka matrix opal. These treated samples range from 4.73 to 13.69 ct. Photo $(\mathcal{O}$ GA and Tino Hammid.

of a sandy boulder bed (conglomerate band or concrete) with an underlying water-retentive light brown, yellow, or grayish white claystone. The boulder bed (which is less than $0.5 \mathrm{~m}$ thick) contains tounded pebbles, cobbles, and boulders of quartzite, silicified shale, and silicified limestone lying at the base of a deeply weathered white claystone known locally as kopi. The clays of the conglomerate band were deposited in a shallow sea during Early Cretaceous times, and the boulders were apparently dropped from rafts of floating sea ice, having been entrapped on nearby beaches by shoreline freezing. The presence of these boulders, which can be over $2 \mathrm{~m}$ across, provided a unique environment for the later deposition of opal and gave rise to several types of opal formation (Barnes and Townsend, 1982), including: painted ladiesthin films of opal filling joints in quartzite boulders; colored concrete-opal cementing pebbles, cobbles, and boulders in the conglomerate band; and matrix - opal partly replacing boulders that were formerly carbonate rich, mainly limestone and dolomite, and filling pore spaces in some sandstone and claystone within the opal level. Opal is also found in thin horizontal seams above the opal level, and filling minor joints and faults both above and below it.

The matrix opal found at Andamooka (again, see figure 2) is predominantly a cream-colored to grayish white porous rock that displays an indistinct patchy play-of-color from its scattered content of included grains and patches of precious opal. However, the range of hues in which Andamooka matrix opal does occur includes porcelain white, gray to black, pink, bright green, gold, and black-and-white splashed peacock matrix (George Brooks, pers. comm., 1991). This rock is better described as matrix opal than as opal matrix since, at Andamooka, opal is found replacing both clasts and matrix (J. Keeling, pers. comm., 1990). In Australia, the occurrence of matrix opal appears to be restricted to the Andamooka opal fields (Barnes and Townsend, 1982), with matrix boulders weighing hundreds of kilos commonly recovered from the opal level.

Figure 2. Before treatment, most Andamooka matrix opal displays little play of color. Here, the largest cabochon is $9.84 \mathrm{ct}$. Photo $\odot$ GIA and Tino Hammid.

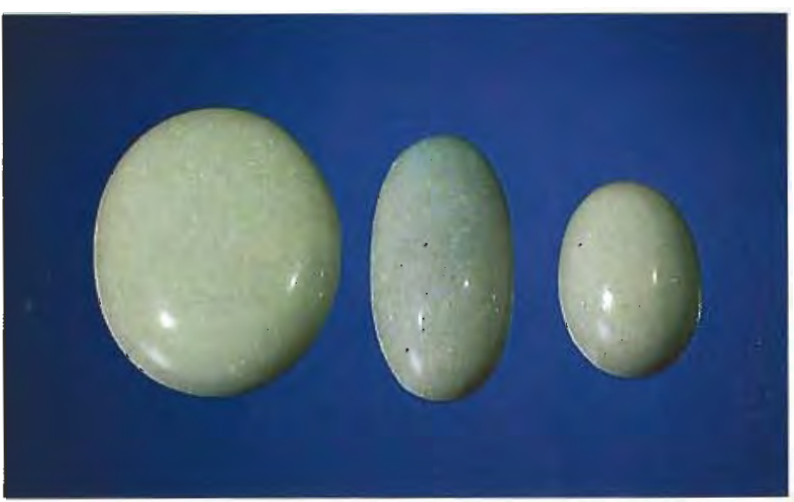


Figure 3. Treated Andamooka opal (lower right, $7.22 \mathrm{ct}$ ) not only resembles natural black opal from Lightning Ridge, Australia, but also oolitic opal (the carving, $35.76 \mathrm{ct}$ ) and black opal from Honduras (upper right, $24.53 \mathrm{ct}$ ). Photo (C) GIA and Tino Hammid.

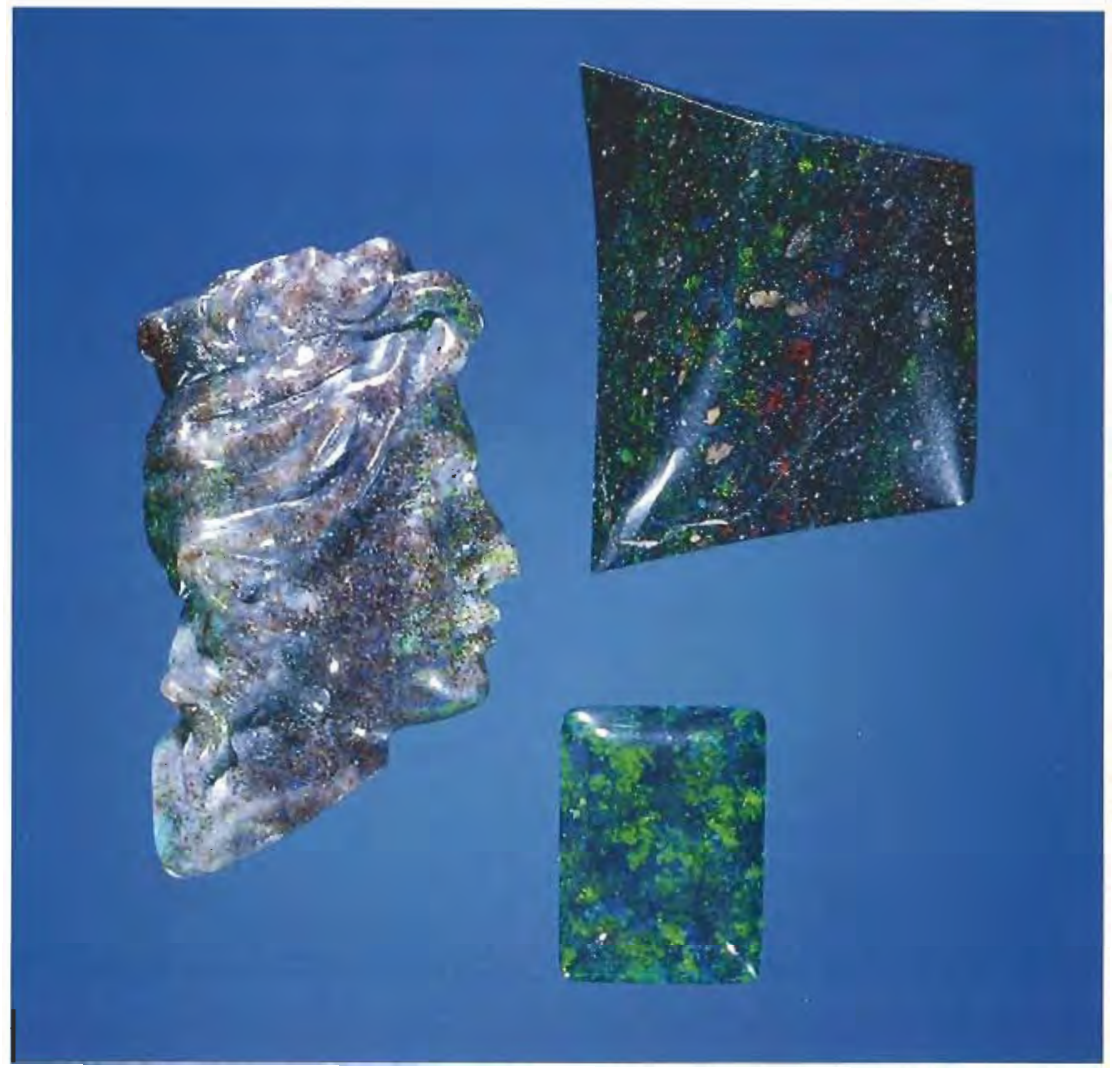

On the basis of their examination of two specimens of Andamooka matrix opal with both optical and scanning electron microscopy, geologists at the Geological Survey of South Australia (Keeling and Farrand, 1984) found that the matrix opal "is composed of an intimate mix of silica spheres and finer grained amorphous or partly crystalline silica." They attribute its relatively high porosity to numerous voids within patches of opal and along the contact zones of the opal with the fine-grained silica. They concluded from their investigation that the matrix opal probably formed when limestone erratics within Cretaceous marine sandy clay were partially dissolved, and the remaining carbonate rock was replaced by finegrained silica at the same time that silica spheres were deposited and grew in existing solution cavities.

It is the intrinsic porosity of Andamooka matrix opal that makes possible the impregnation of its surface with black carbon particles to enhance the play-of-color (figure 5).

\section{TREATED ANDAMOOKA MATRIX OPAL}

Andamooka matrix opal has been color enhanced by carbon impregnation since the mid-1950s (Keeling and Farrand, 1984). For almost four decades, this color-enhanced opal has been variously ter- 
med carbonized matrix opal (McColl, 1966), dyed opal matrix (Altmann, 1979), opal matrix (I. Townsend, pers. comm., 1990), dyed matrix opal (J. Keeling, pers. comm., 1990), and sugar-treated opal (Koivula, 1984).

McColl (1966) provided one of the first comprehensive descriptions of this enhancement technique:

1. The matrix opal is selected for treatment based on the following factors:

- The quality, size, and distribution of precious opal in the individual matrix piece

- The purity, porosity, and fineness of grains in the matrix

- The ability of the nonopaline groundmass to accept a lustrous polish

The best matrix opal for treatment has a clean, sand-free, cream-colored matrix with sufficient porosity to facilitate its impregnation with carbon particles, but will accept a lustrous polish with minimal undercutting.

2. Color enhancement is best performed between the finat sanding and polishing steps, not after polishing. Not only will the impregnation process severely etch the polished surface, but polishing also decreases the permeability of the matrix. In addition, the black carbon impregnator usually only penetrates to a very shallow depth (figure 6).

Figure 5. Treatment of different colors of Andamooka matrix opal (top) produces different types of carbonized matrix opal (bottom). Experienced treaters know which types of untreated material will produce the most attractive carbonized opal.

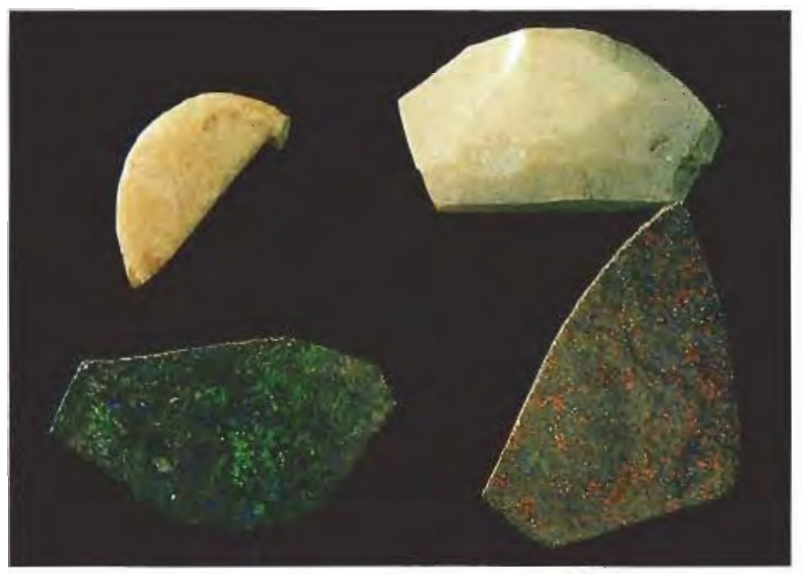

3. The following sugar-acid carbonizing technique is generally used:

Step 1. The surface of the matrix opal is ground and sanded to prepolish smoothness.

Step 2. The prepolished specimen is immersed in two to three times its volume of an acidified glucose-lactose impregnator - a $20 \%$ solution of glucose and lactose, in 1:4 proportions, to which a few drops of concentrated sulfuric acid have been added.

Step 3. The impregnator is heated at $105^{\circ} \mathrm{C}$ for up to 10-12 hours until the solution evaporates. At this point, the temperature is raised to $125^{\circ} \mathrm{C}$, so that the sugars impregnating the matrix opal will solidify and then dehydrate.

Step 4. The sugar-impregnated matrix opal is gently broken from the darkened sugary mass. After excess sugar has been scraped from its surface, the impregnated piece is immersed in a glass vessel filled with concentrated $99 \%$ ) sulfuric acid that is slowly heated to $100^{\circ} \mathrm{C}$ for $4-5$ hours. This treatment reduces the impregnating sugars to black carbon.

Figure 6. In most cases, the carbon treatment penetrates the matrix opal only at the surface of the prepolished stone. Here, the chipped surface of the cabochon at top reveals the whitish color of the original matrix opal. Cut lengthwise, the cabochon at the bottom graphically illustrates the relatively shallow depth of penetration of the carbon.

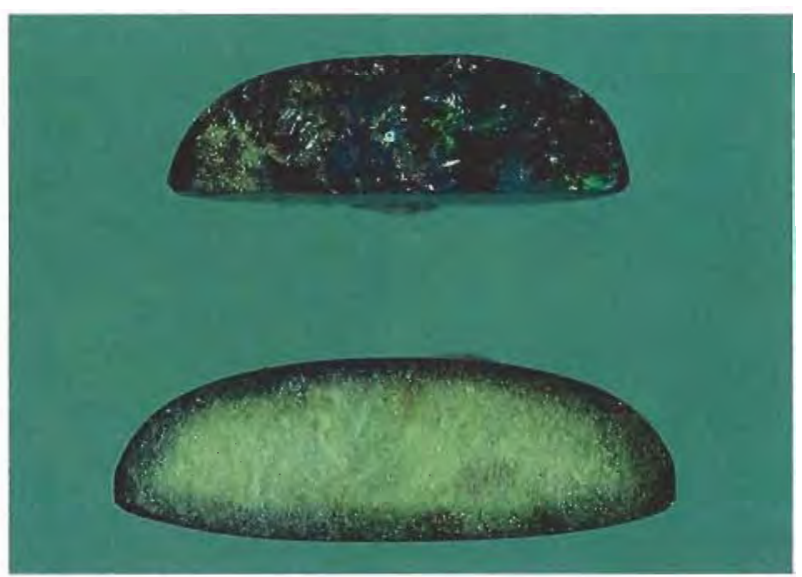




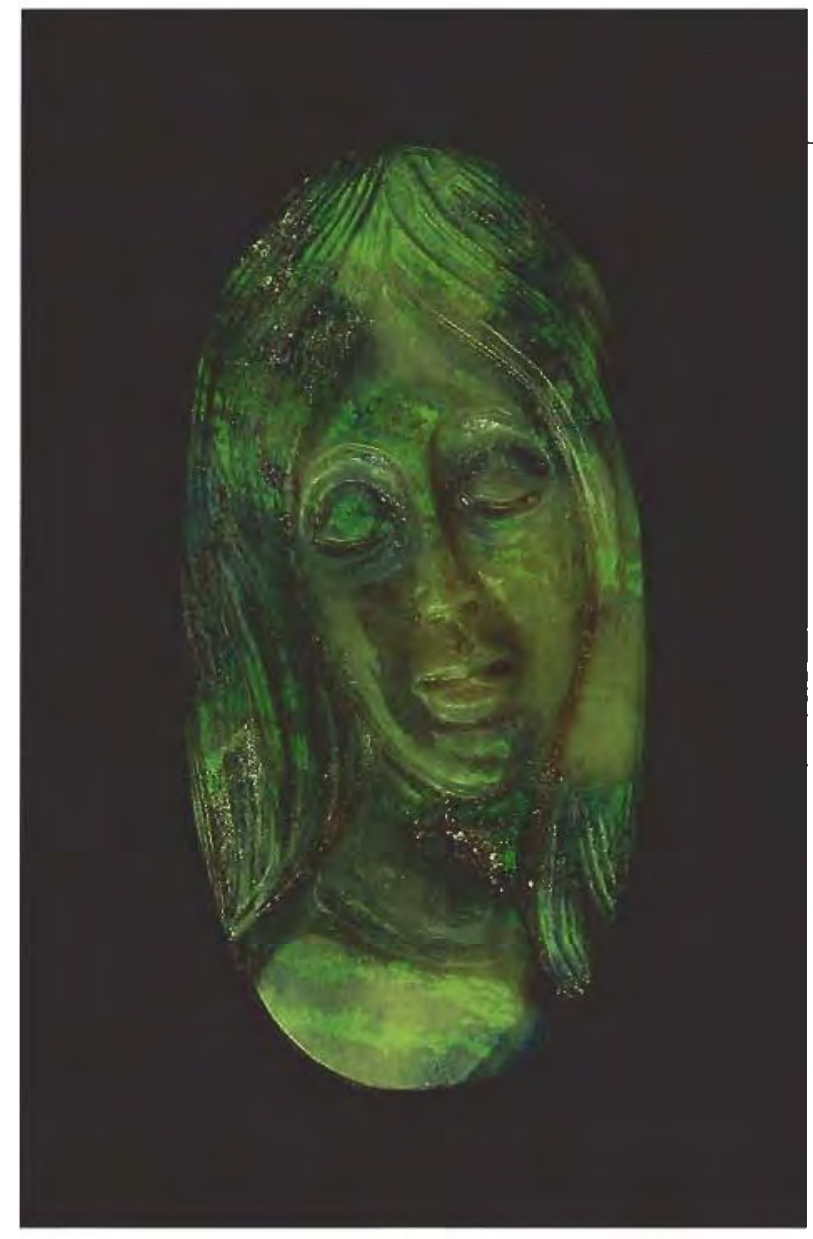

Figure 7. Treated Andamooka matrix opal is used not only in cabochons but also for carvings, such as this $13 \times 26 \mathrm{~mm}$ sample.
Step 5. After slow cooling, the carbonized (carbon-impregnated) matrix opal is washed in running water for 8-12 hours to remove residual sulfuric acid.

Step 6. The treated matrix opal is carefully and lightly polished to minimize removal of the (usually thin) external carbonized layer.

Note that opal itself (potch or precious) cannot be "dyed." Only the matrix a round patches or discrete grains of opal in Andamooka matrix opal will change color.

Although McColl's description of sugar-acid carbonization of Andamooka matrix opal is 25 years old, this same technique-or variations of it -is still being applied today in much the same sequence of steps. As the carbonization of Andamooka matrix opal is mainly a "cottage industry" pursued by various miners, gem merchants, and professional lapidaries throughout Australia, valid estimates of production are impossible to obtain. This lack of reliable production information is not unique to carbonized Andamooka matrix opal. Indeed, virtually all production figures for Australian opal should, at best, be considered either "guesstimates" (on behalf of the government) or precautionary underestimates (on behalf of tax-paying miners).

Figure 8. Some extremely large pieces of Andamooka matrix opal have been treated and are currently in the trade. This approximately 10,500-ct treated Andamooka matrix opal is courtesy of Jim Rose, Opal America. Photo (C) GIA and Tino Hammid.

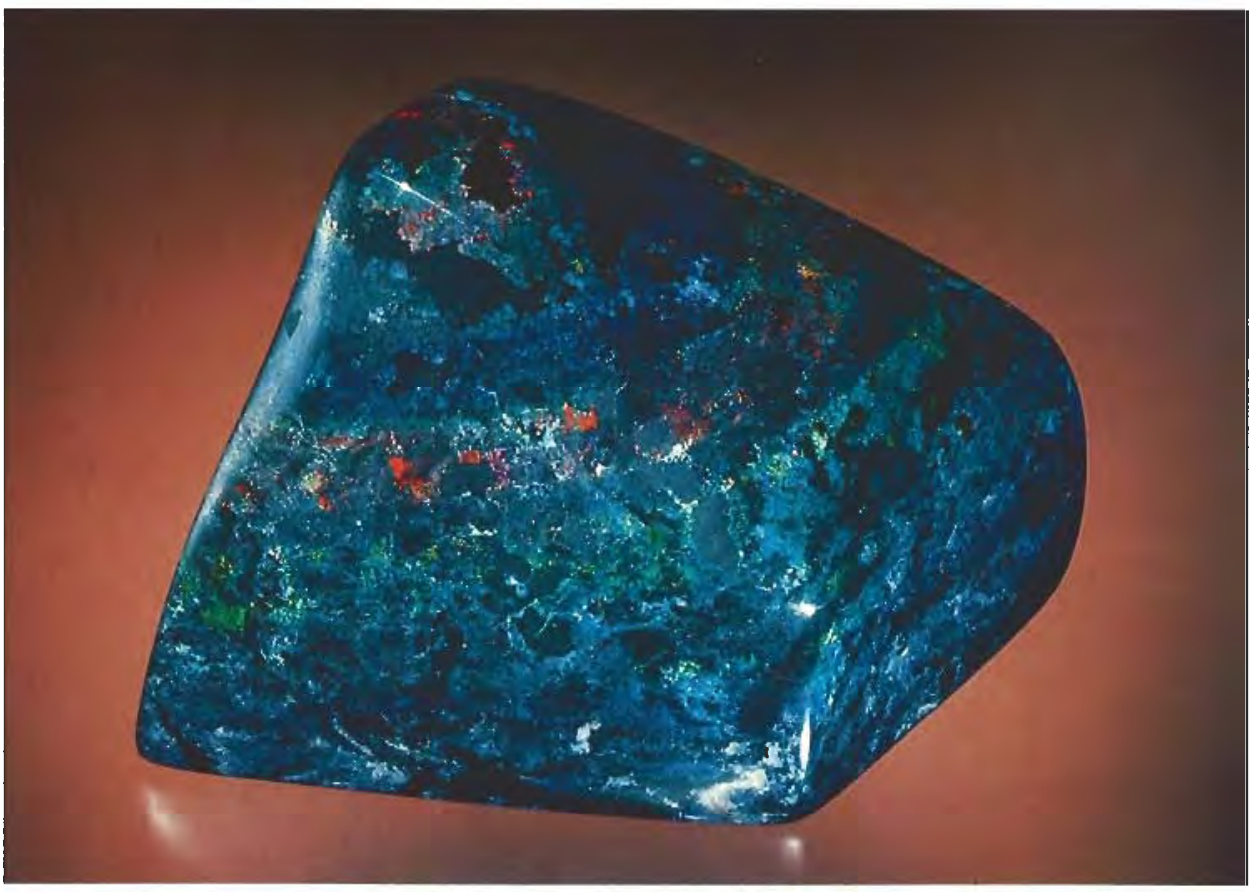



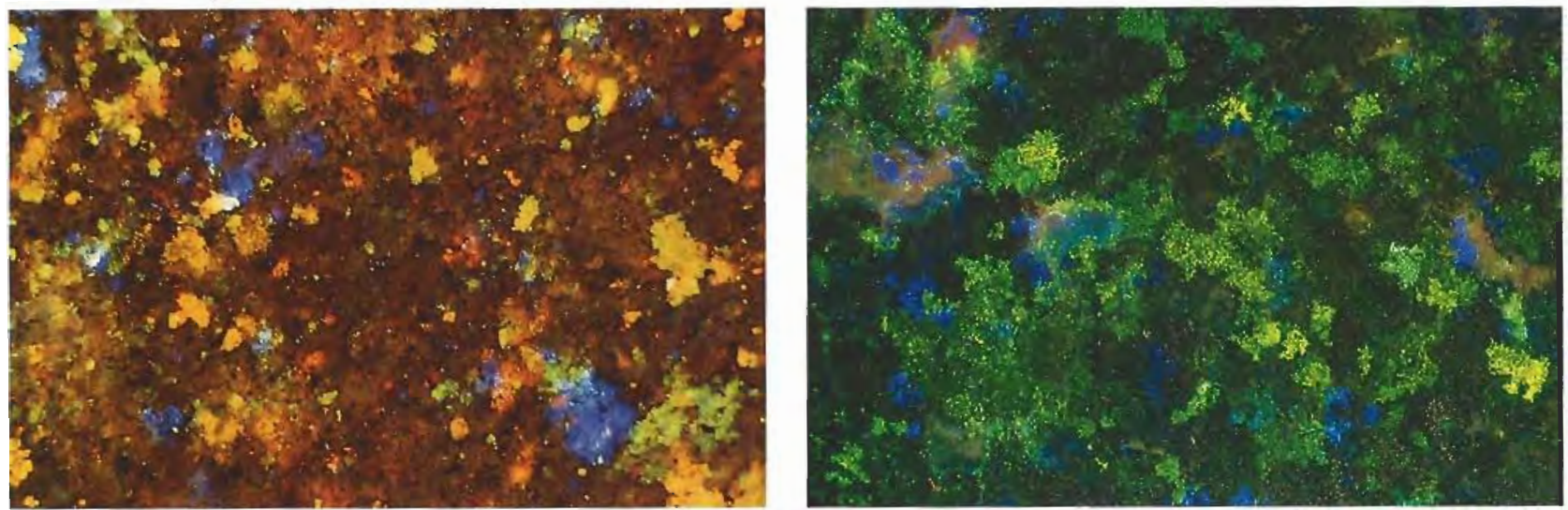

Figure 9. With $10 \times$ magnification (a hand lens), the coarsely granular groundmass of carbon-treated Andamooka matrix opal is readily apparent. In addition, the carbon impregnator can be seen to surround and include randomly distributed, irregularly sized patches of precious opal. Photo on left is by the author; photo on right is by Robert Weldon.

Carbonized Andamooka matrix opal is now available on the international gem market, both as cabochons (again, see figure 1) and carvings (figure 7). Some extremely large "boulders" have also been treated (figure 8). Inasmuch as some of the carbonized opals have been misidentified as black opal in the gem community, the following guidelines are provided.

\section{IDENTIFICATION OF TREATED ANDAMOOKA OPAL}

The matrix of this material will have a siliceous groundmass with a macroscopic texture that ranges from smoothly opal-like to fine or coarsely granular. Regardless of the texture, the presence of the black carbon impregnator is readily visible with magnification (using a $10 \times$ loupe or lowpower binocular microscopel and carefully directed incident illumination. The treatment can be seen either in and around scattered patches of precious opal (figure 9), or filling voids and fractures in the surrounding nonprecious opal siliceous matrix (figure 10).

While treated Andamooka matrix opal has been used to imitate valuable Lightning Ridge black opal, side-by-side comparisons will reveal the following discriminatory features (figure 11):

1. Treated Andamooka matrix opal never displays the velvety lustrous polish of Lightning Ridge black opal.

2. The body color of treated Andamooka matrix opal is opaque and uniformly black. In contrast, the translucent to opaque body color of Lightning Ridge black opal is typically dark blue, dark green, dark brown, or gray, and only very rarely black.

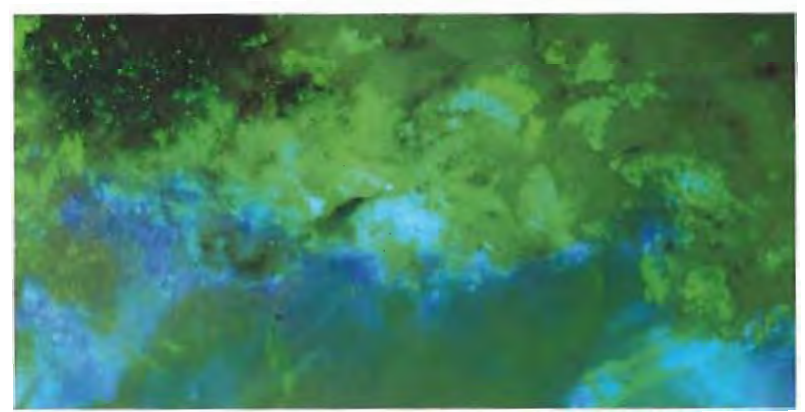

Figure 10. Black carbon particles can also be seen filling voids, fractures, and surface defects in carbonized Andamooka matrix opal that has an essentially opaline groundmass. Magnified $10 \times$.

Figure 11. Treated Andamooka matrix opal (left, $13.69 \mathrm{ct}$ ) may be mistaken for Lightning Ridge black opal (right, $11.88 \mathrm{ct}$ ), although there are several distinguishing characteristics. Photo (C) GIA and Tino Hammid.

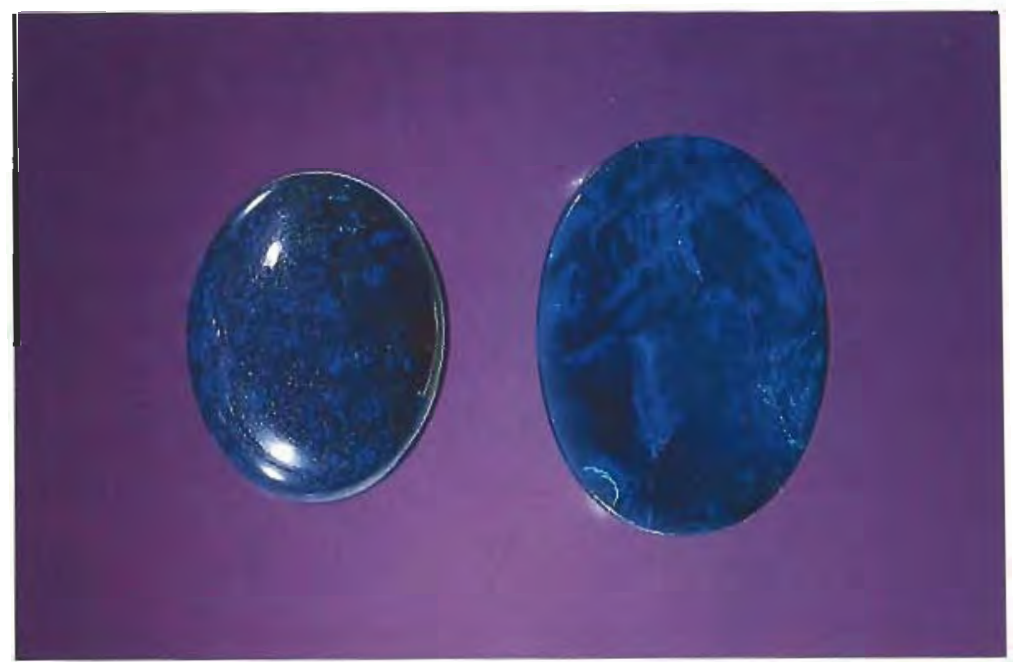


3. Treated Andamooka matrix opal has patchy to spotty play-of-color that emanates from an obvious black carbon-impregnated matrix.

As treated Andamooka matrix opal has quite distinctive hand-lens characteristics, other gemological tests will seldom be needed to identify this treated opal. Depending on the porosity of the original material, this color-enhanced matrix opal has gemological properties (hardness $=6$, specific gravity $=1.98$ to 2.05 , a "spot" refractive index of $1.44 / 1.45$, and patchy blue-white fluorescence to long-wave ultraviolet radiation) that are identical to those of solid light-colored Andamooka opal.

Owners of treated Andamooka matrix opals should avoid damage to the surface of the stone, because the carbon impregnation often is no deeper than $1 \mathrm{~mm}$ (although the immersion of a particularly porous matrix opal in the sugar solution for several days may alter the color throughout the entire stone; G. Brooks, pers. comm., 1990). While treated Andamooka matrix opal has the same toughness as solid Andamooka opal, the color in the treated opal may be removed by repolishing.

\section{CONCLUSION}

In Australia, the term matrix opal is used to describe a range of sandy, clay-like, or siliceous rocks that have their pore spaces and fractures filled with precious opal. Almost all treatable matrix opal comes from the Andamooka opal fields in South Australia.

For almost 40 years, Andamooka matrix opal has been color enhanced by sugar-acid treatment of the prepolished matrix opal.

Dyed Andamooka matrix opal is simple to identify, because at $10 \times$ magnification the black particulate carbon impregnator can be seen either within or surrounding discrete grains of precious opal, or impregnating the nonopaline siliceous matrix surrounding these patches of color.

\section{REFERENCES}

Altmann J.D. (1979) Suggestions for nomenclature of opals. Australian Gemmologist., Vol. 13, No. 12, pp. 383-385. Barnes L.C., Townsend 1.J. (1982) Opal: South Australian Gemstone. South Australia Department of Mines and Energy, Adelaide, SA.

Keeling J.L., Farrand M.G. (1984) Origin and formation of matrix opal from Andamooka, South Australia. Quarterly Geological Notes of the Geological Survey of South Australia, No. 90, pp. 3-10.

Koivula J.1. (1984) Gem trade lab notes: Opal, oolitic vs. sugar treated. Gems \&) Gemology,Vol. 20, No. 4, p. 229.

McColl D.H. (1966) Matrix opal-Unique South Australian gemstone. Australian Gemhunter, Vol. 1, No. 3, pp. 6-11.

South Australia Department of Mines and Energy [SADME] (1989) SA opal production, 1988. Mineral Industry Quarterly South Australia, No. 54, p. 30.

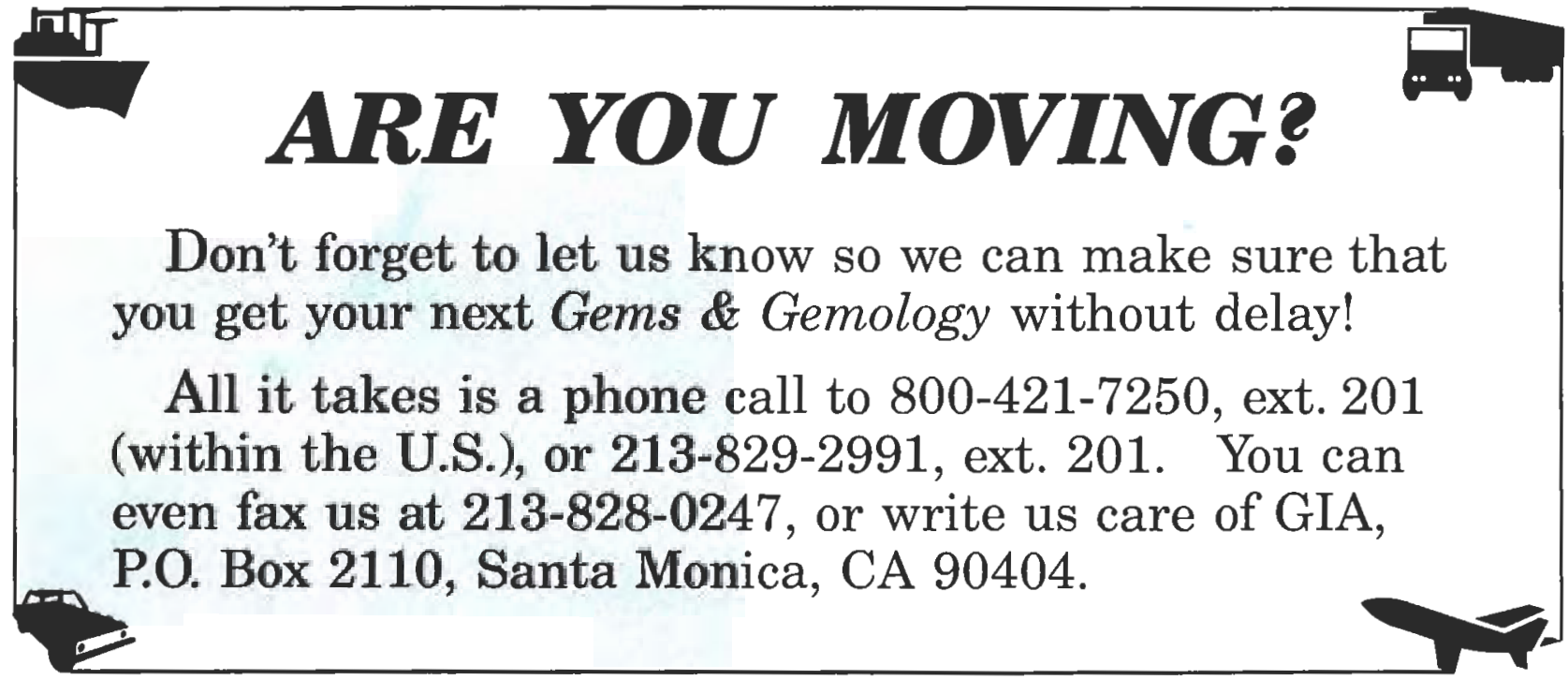

